\title{
Heterodimerization of the transcription factors E2F-1 and DP-1 leads to cooperative trans-activation
}

\author{
Kristian Helin, ${ }^{1}$ Chin-Lee Wu, Ali R. Fattaey, Jacqueline A. Lees, Brian D. Dynlacht, Chidi Ngwu, \\ and Ed Harlow \\ Massachusetts General Hospital Cancer Center, Charlestown, Massachusetts 02129 USA
}

\begin{abstract}
The E2F transcription factor has been implicated in the regulation of genes whose products are involved in cell proliferation. Two proteins have recently been identified with E2F-like properties. One of these proteins, E2F-1, has been shown to mediate E2F-dependent trans-activation and to bind the hypophosphorylated form of the retinoblastoma protein (PRB). The other protein, murine DP-1, was purified from an E2F DNA-affinity column, and it was subsequently shown to bind the consensus E2F DNA-binding site. To study a possible interaction between E2F-1 and DP-1, we have now isolated a cDNA for the human homolog of DP-1. Human DP-1 and E2F-1 associate both in vivo and in vitro, and this interaction leads to enhanced binding to E2F DNA-binding sites. The association of E2F-1 and DP-1 leads to cooperative activation of an E2F-responsive promoter. Finally, we demonstrate that E2F-1 and DP-1 association is required for stable interaction with pRB in vivo and that trans-activation by E2F-1/DP-1 heterodimers is inhibited by PRB. We suggest that "E2F" is the activity that is formed when an E2F-1-related protein and a DP-1-related protein dimerize.
\end{abstract}

[Key Words: E2F/DP-1; retinoblastoma protein; heterodimerization; trans-activation]

Received July 1, 1993; revised version accepted August 11, 1993.

The transcription factor E2F was originally identified as a cellular protein whose DNA-binding activity was stimulated upon adenovirus infection of cultured cells (Kovesdi et al. 1986; for review, see Nevins 1992; Helin and Harlow 1993). This transcription factor appears to regulate the temporal expression of certain genes whose products are involved in cell proliferation. E2F DNAbinding sites have been identified in promoters for genes such as c-myc, N-myc, cdc2, DHFR, and DNA polymerase $\alpha$ (Blake and Azizkhan 1989; Thalmeier et al. 1989; Pearson et al. 1991; Dalton 1992). In the c-myc, cdc2, and DHFR promoters the E2F sites have been demonstrated to contribute to transcriptional activation (Blake and Azizkhan 1989; Hiebert et al. 1989; Thalmeier et al. 1989; Dalton 1992). Furthermore, the presence of a single E2F DNA-binding site in the DHFR promoter has been shown to be sufficient for the proper temporal expression of the DHFR gene (Means et al. 1992; Slansky et al. 1993).

E2F is present in multiple complexes in the cell when bound to DNA (Bagchi et al. 1990). These complexes include key regulators of cell proliferation, such as the retinoblastoma protein (pRB) (Bagchi et al. 1991; Bandara and La Thangue 1991; Chellappan et al. 1991; Chittenden et al. 1991), and the pRB-related proteins, p107,

${ }^{1}$ Corresponding author. which is associated in a complex with cyclin A/cdk2 or cyclin E/cdk2 (Bandara et al. 1991; Cao et al. 1992; Devoto et al. 1992; Lees et al. 1992; Shirodkar et al. 1992) and p130 (D. Cobrinik and R. Weinberg, pers. comm.). Several observations suggest that the association of E2F with these cellular proteins regulates its activity: E2F associates with the underphosphorylated form of $\mathrm{pRB}$ (Chellappan et al. 1991; Helin et al. 1992), which is a negative regulator of cell proliferation (Goodrich et al. 1991; Hinds et al. 1992; Qin et al. 1992). These observations led to the suggestion that $\mathrm{pRB}$ negatively regulates the activity of E2F by binding to this transcription factor.

Experimental evidence for this hypothesis has been obtained from transfection experiments in which overexpression of pRB has been shown to decrease E2F-dependent transcription (Hamel et al. 1992; Hiebert et al. 1992; Zamanian and La Thangue 1992; Helin et al. 1993). In a similar manner, it has been demonstrated that overexpression of p107 leads to decreased E2F activity (Schwarz et al. 1993; Zamanian and La Thangue 1993; Zhu et al. 1993). The functional consequences of the cyclin $\mathrm{A} / \mathrm{cdk} 2$ or cyclin $\mathrm{E} / \mathrm{cdk} 2$ kinase interaction with p107 have yet to be established, and it is still a possibility that E2F in association with one or several of the described cellular proteins is active. Interestingly, the adenovirus ElA proteins associate with pRB, p107, and p130 (Yee and Branton 1985; Harlow et al. 1986), and the binding of ElA to these proteins has been shown to dis- 
sociate E2F, thereby generating "free E2F" (Bagchi et al. 1990 ). In this setting E1A is a potent activator of E2Fmediated transcription (Yee et al. 1989). The ability of E1A to release free E2F and activate transcription through E2F-binding sites suggests that E2F in its free form is the active transcription factor, thereby supporting the notion that the E2F-associated proteins are negative regulators of $\mathrm{E} 2 \mathrm{~F}$ activity.

A cDNA encoding a protein with many of the properties of human E2F has been cloned (Helin et al. 1992; Kaelin et al. 1992; Shan et al. 1992). This protein, called E2F-1, was shown to bind to pRB in vivo and in vitro (Helin et al. 1992; Kaelin et al. 1992; Shan et al. 1992). Furthermore, when transfected into cultured cells, E2F-1 was able to mediate transcription dependent on the presence of E2F DNA-binding sites (Helin et al. 1992; Shan et al. 1992). Structural analyses have shown that E2F-1 contains discrete domains capable of mediating DNA binding, trans-activation, and pRB binding (Helin et al. 1992; Kaelin et al. 1992; Shan et al. 1992). The pRB-binding domain of E2F-1 is situated within the trans-activation region, and further analysis has demonstrated that direct binding of pRB to E2F-1 is required for inhibition of E2F1-dependent trans-activation (Helin et al. 1993).

Although free E2F is thought to be the active protein for trans-activation, it appears that more than one polypeptide is needed to create a high-affinity E2F-DNA interaction (Huber et al. 1993). Recently, another protein with some of the properties of E2F has been identified in murine cells (Girling et al. 1993). A cDNA for this protein, called DP-1, was isolated, and the bacterially produced protein was shown to have some affinity for an E2F DNA-binding site (Girling et al. 1993). The existence of two E2F DNA-binding proteins, together with the observation that E2F probably binds DNA as a heterodimer, led us to investigate whether there was an interaction between E2F-1 and DP-1. We have isolated the cDNA for human DP-1 and show that the human DP-1 can bind to E2F-1 in vivo and in vitro. Furthermore, we show that the interaction between E2F-1 and DP-1 leads to enhanced binding to E2F sites and increased transactivation of a promoter containing these sites. Finally, we demonstrate that E2F-1 and DP-1 heterodimerization is required for stable interaction with $\mathrm{pRB}$ and that trans-activation by E2F-1/DP-1 heterodimers is inhibited by $\mathrm{pRB}$.

\section{Results}

\section{Isolation of the CDNA for human DP-1}

To analyze the involvement of DP-1 in E2F complexes, we isolated a cDNA clone for human DP-1 from an expression library constructed from human Nalm 6 pre-B cells as described in Materials and methods. The isolated clone contained an open reading frame of 410 amino acids with a predicted molecular mass of $45 \mathrm{kD}$ (Fig. 1). Amino acid alignment of human and mouse DP- 1 shows a high degree of conservation between species $195 \%$ identical). The amino acid sequence of the mouse DP-1 clone

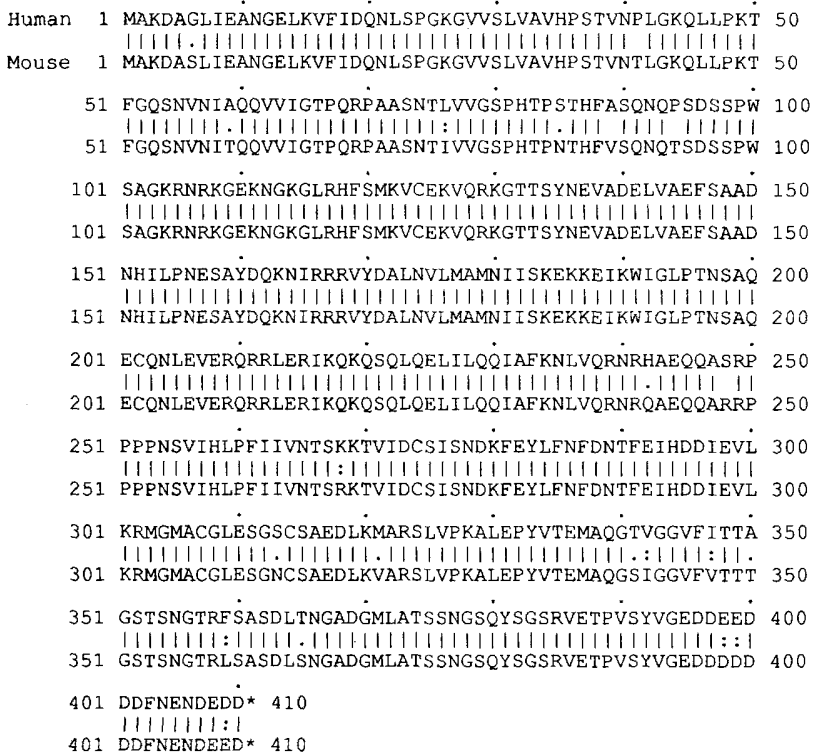

Figure 1. Amino acid alignment of human DP-1 and mouse DP-1. Alignment of the predicted open reading frames of human (top) and mouse DP-1s show that the two proteins are 95\% identical. The cDNA for human DP-1 contains an open reading frame of 410 amino acids and a predicted molecular mass is of 45,070 daltons. We have modified the open reading frame of mouse DP-1 relative to the published sequence /Girling et al. 1993|, because we have identified an additional cytosine at nucleotide 1218 in mouse DP-I, numbered according to Girling et al. (1993). This additional nucleotide changes the reading frame of the last 40 amino acids compared with the published sequence, and the mouse $D P-1$ gene therefore encodes a 410 amino-acid protein with a predicted molecular mass of $\sim 45 \mathrm{kD}$.

depicted in Figure 1 is slightly different than that published by Girling et al. (1993). Sequencing of mouse $D P-1$ (kindly provided by R. Girling) identified an extra cytosine at nucleotide 1218 (numbered according to Girling et al. 1993|, which changes the reading frame of the last 40 amino acids in the published sequence. Thus, the open reading frame of mouse DP- 1 is 410 amino acids and not 429 amino acids as published previously. The GenBank accession number of the human DP-1 DNA sequence is L23959.

\section{E2F-1 and DP-1 heterodimerize in vitro}

Recent studies have suggested that the activity called "E2F" binds DNA as a heterodimer and that E2F-1, in particular, associates with other proteins to promote a stable interaction with DNA (Huber et al. 1993; K. Helin, unpubl.). Because DP-1 was purified and characterized as a protein associated with E2F DNA-binding activity, it was a likely candidate for an E2F-1 partner. To test whether DP-1 would bind to E2F-1 in solution, fulllength human DP-1 was synthesized in vitro and mixed with various E2F-1 wild-type and mutant glutathione $S$-transferase (GST) fusion proteins (Fig. 2A). The in vitro-translated DP-1 had an apparent molecular mass of $52 \mathrm{kD}$ and did not bind to the GST control. However, it 


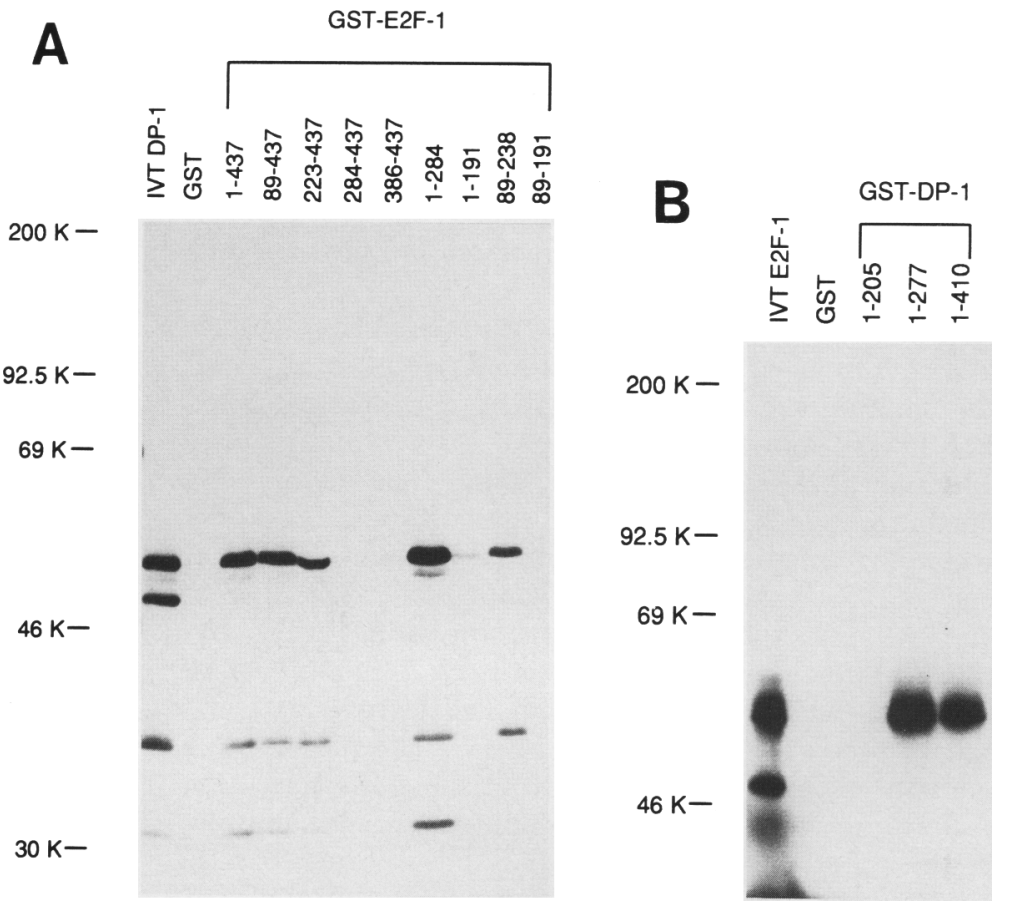

Figure 2. E2F-1 and DP-1 heterodimerize in vitro. (A) Mapping of regions in E2F-1 required for binding to DP-1. A panel of GST fusion proteins of E2F-1 were made as described in Materials and methods. The fusion proteins $(5 \mu \mathrm{g})$ were tested for binding to in vitro-translated DP-1 $(5 \mu$ l). The numbers above each lane refer to the amino acid sequence contained in each GST-E2F-1 construct. As a control for binding efficiency, $1 \mu \mathrm{l}$ of in vitro-translated DP-1 (IVT DP-1) was separated on the polyacrylamide gel. (B) Mapping of regions in DP-1 required for binding to E2F-1. Three GST-DP-1 fusion proteins of DP-1 | 5 $\mu \mathrm{g})$ were tested for binding to in vitro-translated E2F-1 $(10 \mu l)$ as described in Materials and methods. The numbers above each lane refer to the amino acid sequence contained in each GST-DP-1 construct. One microliter of in vitro-translated E2F-1 (IVT E2F1) was loaded on the polyacrylamide gel as a control for binding efficiency.

bound tightly to a GST fusion protein containing the full-length E2F-1. By testing a series of GST-E2F-1 fusion proteins, a domain of E2F-1 between amino acids 191 and 284 was mapped to be required for interaction with DP-1. This region of E2F-1 has some homology to DP-1 (Girling et al. 1993) and includes a putative leucine zipper (Kaelin et al. 1992). Our data also suggested that the small domain containing amino acids 223-238 would be sufficient for binding (amino acids 223-437 and 89-238; Fig. 2A). However, when a GST fusion protein containing these amino acids of E2F-1 was mixed with in vitro-translated DP-1, no detectable binding of DP-1 was observed (data not shown), suggesting that other regions of E2F-1 are required for stable interaction with DP-1. The binding experiments also demonstrated that the DNA-binding domain of E2F-1 (Helin et al. 1992) was not sufficient for E2F-1 binding to DP-1 (amino acids 1-191 and 89-191; Fig. 2A). Furthermore, the carboxyterminal part of E2F-1 did not mediate the interaction between E2F-1 and DP-1 (amino acids 284-437 and 386437; Fig. 2A), suggesting that neither the trans-activation domain (Kaelin et al. 1992) nor the pRB-binding domain of E2F-1 (Helin et al. 1992) is required for DP-1 binding.

To delineate the regions of DP-1 required for binding to E2F-1, GST-DP-1 fusion proteins corresponding to either the full-length DP-1 protein, amino acids 1-277, or amino acids 1-205 were produced. As shown in Figure $2 \mathrm{~B}$, the full-length DP-1 fusion protein and the fusion protein containing amino acids $1-277$ bound in vitrotranslated E2F-1, whereas GST-DP-1 containing amino acids 1-205 did not. These data suggest that a region between amino acids 205 and 277 of DP-1 is required for binding and that the DNA-binding domain of DP-1 de- scribed previously (amino acids 84-204; Girling et al. 1993 ) is not sufficient for this interaction to occur.

\section{E2F-1/DP-1 heterodimers bind DNA}

Because we have demonstrated that E2F-1 binds to DP-1 in solution, we then wanted to determine whether the two proteins would bind DNA as heterodimers. We have shown previously that a GST-E2F-1 fusion protein containing amino acids 89-191 of E2F-1 binds specifically to an E2F site (Helin et al. 1992). To test for heterodimerization of E2F-1 and DP-1, a GST-E2F-1 protein containing the sequences necessary for both DNA binding and dimerization (amino acids 1-284) was used. As expected, this fusion protein bound to the E2F DNA-binding site (Fig. 3), and upon addition of GST-DP-1 (1-277), increased DNA binding was observed. In addition, the binding of the GST-DP-1 protein resulted in a slightly slower migrating band than the one observed for GSTE2F-1 (1-284) alone. Surprisingly, the GST-DP-1 (amino acids 1-277) and the GST-DP-1 (1-205) did not give rise to any detectable E2F DNA-binding activity in our assays (Fig. 3; data not shown), even when they were used at $10 \times$ higher concentrations than used for GST-E2F-1. These data suggest that human DP-1 has much lower affinity for the E2F DNA-binding site than human E2F-1. Furthermore, the data indicate that the same regions of DP-1 are required for dimerization with E2F-1 in solution and when bound to DNA.

To test for specificity in the DNA-binding experiments, GST-E2F-1 (1-284) was cleaved with thrombin. As shown in Figure 3, no detectable binding of E2F-1 (1-284) was observed when $20 \mathrm{ng}$ of the protein was used in the gel-retardation assay. However, DNA binding was 

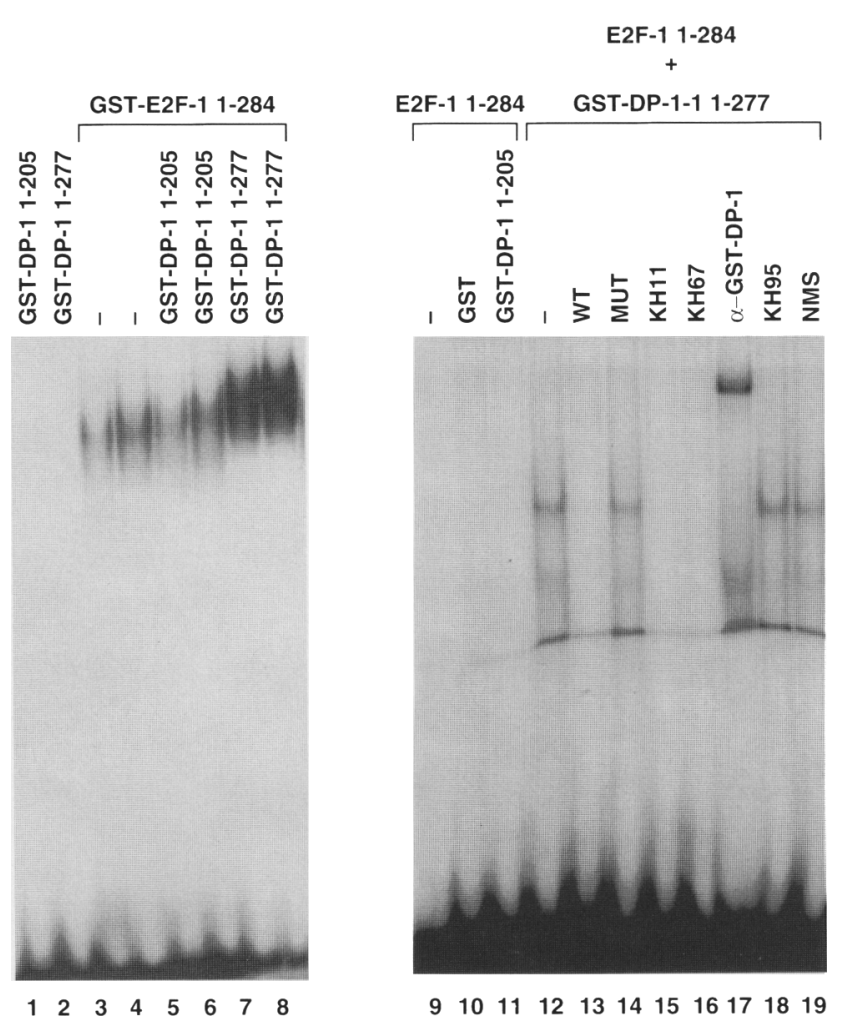

Figure 3. E2F-1/DP-1 heterodimers bind DNA. GST fusion proteins were tested for binding to a ${ }^{32} \mathrm{P}$-labeled oligonucleotide containing the E2F consensus site as described in Materials and methods. One hundred nanograms (lanes 1,2,6,8), 50 ng (lanes 5,7 ), or $20 \mathrm{ng}$ (lanes 11-19) of GST-DP-1 proteins was tested for DNA binding in the absence or presence of GST-E2F-1 (lanes 5-8) or E2F-1 (lanes 11-19). Fifty nanograms of GST-E2F-1 or 20 ng of E2F-1 was tested for DNA binding, except in lane 4 where $100 \mathrm{ng}$ of GST-E2F-1 fusion protein was tested. Numbers after the proteins refer to the amino acids contained in each E2F-1 or DP-1 protein. E2F-1 1-284 refers to an E2F-1 protein in which the GST portion was cleaved off. The specificity of binding was tested by the addition of antibodies $(1 \mu \mathrm{l})$. The antibodies were monoclonal antibodies to E2F-1 (KH11, KH67, and KH95), a polyclonal mouse antisera to GST-DP-1 ( $\alpha$-GST-DP-1), and normal mouse serum (NMS). NMS and KH95 (epitope in E2F-1 between amino acids 342 and 386) served as control antisera.

restored upon incubation with GST-DP-1 (1-277). The binding to DNA was specific to E2F-1 and DP-1, because antibodies to E2F-1 (KH11 and KH67) and GST-DP-1 ablated (anti-E2F-1) or supershifted (anti-DP-1) the retarded bands, whereas control antibodies [KH95 (E2F-1 epitope: amino acids 342-386) and normal mouse serum] had no effect.

\section{E2F-1 and DP-1 heterodimerize in vivo}

Several E2F-1 and DP-1 expression plasmids were generated to determine whether the two proteins can dimerize in vivo. The plasmids were transfected into a human cervical carcinoma cell line, C-33A, which expresses a nonfunctional pRB protein (Scheffner et al. 1991). All
DP-1 constructs were tagged with the influenza HA epitope, which is recognized by the 12CA5 antibody (Field et al. 1988). Monoclonal antibodies to pRB (XZ77), E2F-1 (KH20), or 12CA5 did not immunoprecipitate any easily detectable specific bands from ${ }^{35} \mathrm{~S}$-labeled cell lysates (Fig. 4A, lanes 1-3; note that the 12CA5 antibody cross-reacts with an endogenous $80-\mathrm{kD}$ protein). However, upon transient transfection, the various forms of E2F-1 and DP- 1 were readily detected by immunoprecipitation (Fig. 4A). Overexpressed full-length E2F-1 migrated with the expected size of $\sim 60 \mathrm{kD}$ (Fig $4 \mathrm{~A}$, lane 5 ), and E2F-1 (amino acids 1-284) was detected as an $\sim 38$ $\mathrm{kD}$ protein (Fig. 4A, lane 8). The tagged full-length DP-1 protein was detected as a $52-\mathrm{kD}$ protein (Fig. 4A, lane 12), and a shorter form of DP-1 (amino acids 1-205) was recognized as a $33-\mathrm{kD}$ protein (Fig. 4A, lane 15).

To evaluate whether E2F-1 and DP-1 can associate in vivo, C-33A cells were transiently cotransfected with expression plasmids containing E2F-1 and DP-1 cDNAs. As shown in Figure 4B, cotransfection of full-length E2F-1 and full-length DP-1 resulted in stoichiometric coimmunoprecipitation of the two proteins. This interaction was not observed when cells were cotransfected with expression plasmids containing full-length E2F-1 and DP-1 1205), but it was observed when cells were transfected with E2F-1 (1-284) and full-length DP-1. These results demonstrate that E2F-1 and DP-1 can bind in vivo and that the binding is dependent on the regions of the proteins mapped to be important for the association in vitro (Figs. 2 and 3). The observed quantitative binding suggests that other factors are not limiting for this association.

\section{E2F-1 and DP-1 dimerization is required for stable $p R B$ binding}

We have shown previously in vivo association between endogenous pRB and E2F-1 (Helin et al. 1992). However, we have subsequently observed that overexpression of E2F-1 and pRB in cultured cells does not give rise to increased interaction between E2F-1 and pRB (Fig. 4C; K. Helin, unpubl.). Therefore, to determine whether overexpression of DP-1 would lead to an increase in interaction between E2F-1 and pRB, triple transfection experiments were performed. When an expression plasmid encoding full-length $\mathrm{pRB}$ was transfected into C-33A cells, pRB was readily detectable (Fig. 4C, lane 1). Cotransfection of expression plasmids containing full-length E2F-1 and $\mathrm{pRB}$ did not result in any detectable association between pRB and E2F-1 (Fig. 4C, lanes 4,5). Similarly, overexpression of DP-1 with pRB did not lead to any detectable association between these two proteins (Fig. 4C, lanes 7,9). However, coexpression of pRB, E2F-1, and DP-1 resulted in a highly stable interaction between the three proteins (Fig. 4C, lanes 10-12).

To determine the contribution of E2F-1 and DP-1 to the binding of this heterodimer to pRB, E2F-1 (1-284) was expressed with DP- 1 and pRB. Bacterially expressed E2F-1 (1-284) is unable to bind pRB (data not shown) but retains its ability to interact with DP-1. When this E2F-1 

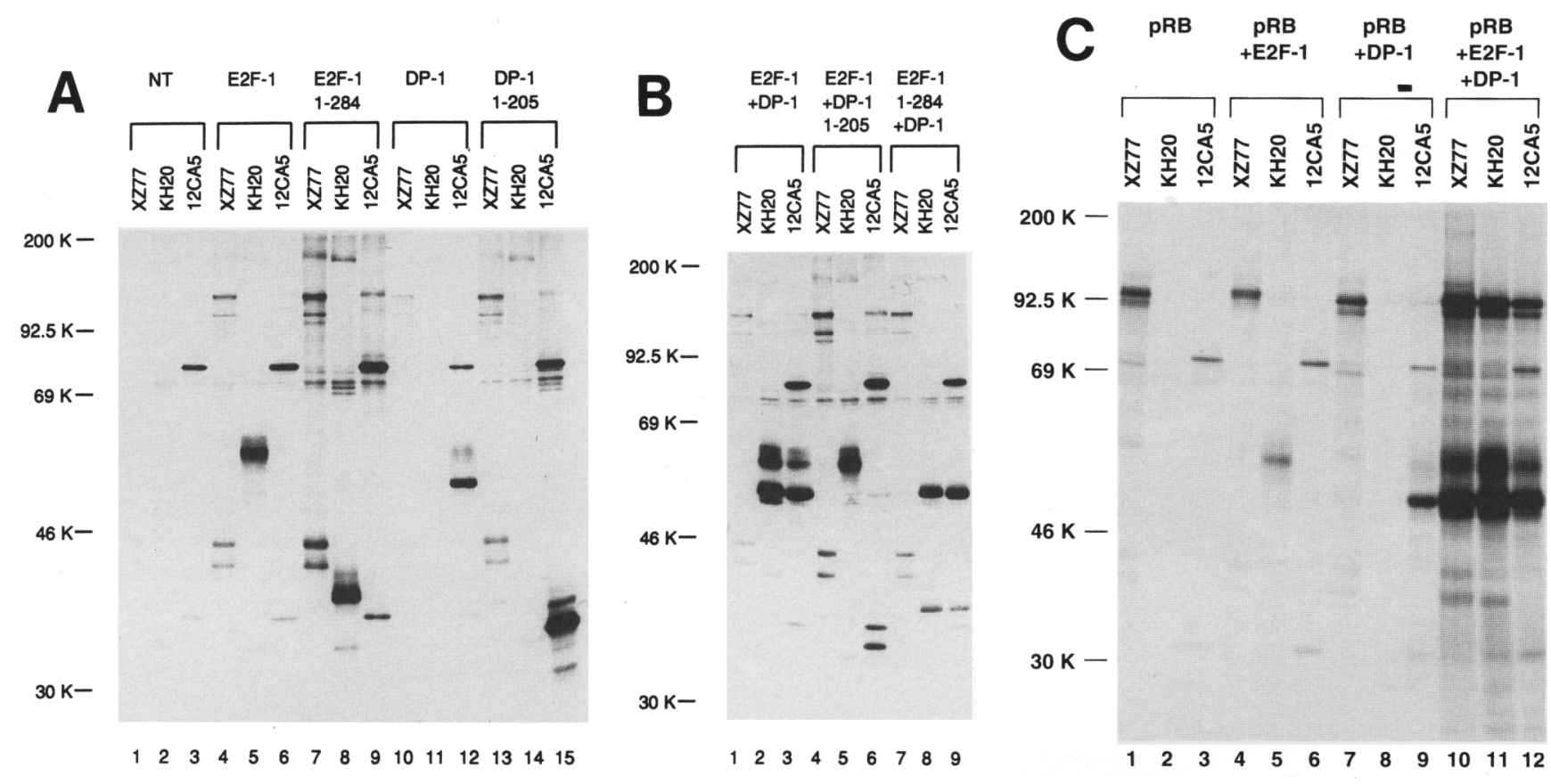

Figure 4. In vivo association of E2F-1, DP-1, and pRB. (A) The human cervical carcinoma cell line C-33A was transfected with the indicated CMV expression plasmids as described in Materials and methods. Cells were ${ }^{35} \mathrm{~S}$-labeled $36 \mathrm{hr}$ after transfection, and expression of proteins was tested by immunoprecipitation. The monoclonal antibodies used for immunoprecipitation were against pRB (XZ77), E2F-1 (KH20), and HA (12CA5). Expression plasmids coded for E2F-1 (amino acids 1-437, full length), E2F-1 1-284 (amino acids 1-284), DP-1 (HA-tagged DP-1, amino acids 1-410, full length), and DP-1 (amino acids 1-205). NT indicates nontransfected cells. $(B)$ E2F-1 and DP-1 associates in vivo. C-33A cells were transiently cotransfected with expression plasmids as indicated above each lane. In vivo association was evaluated by immunoprecipitation as described in $A$. (C) E2F-1/DP-1 heterodimers are required for high-affinity pRB binding. C-33A cells were transiently transfected with expression plasmids as indicated. In vivo association was evaluated by immunoprecipitation as described in $A$. Equal amounts of cell lysates were used for immunoprecipitation in the different transfection experiments.

protein was coexpressed with full-length DP-1 and pRB, it was shown to bind to DP-1 but not to pRB (data not shown), suggesting that the pRB-binding domain of E2F-1 is required for a stable interaction of the three proteins. This result may also suggest that the majority of the pRB-binding capacity of the E2F-1/DP-1 heterodimer is the result of the carboxyl terminus of E2F-1.

\section{Coexpression of E2F-1 and DP-1 leads to increased E2F DNA-binding activity}

The gel-retardation assays performed with bacterially expressed proteins suggest that the E2F-1/DP-1 heterodimers bind the E2F DNA-binding site with higher affinity than either protein alone (Fig. 3) To examine whether this result could be confirmed in vivo, cell extracts from C-33A cells transfected with the E2F-1, DP-1, and $\mathrm{pRB}$ expression plasmids were tested for E2F DNAbinding activity. As shown in Figure 5, expression of either E2F-1 or DP-1 alone did not result in increased E2F DNA-binding activity. However, coexpression of E2F-1 with DP-1 resulted in a 50- to 100-fold increase in DNAbinding activity (Fig. 5A). This increase was dependent on the formation of E2F-1 and DP-1 heterodimers, because cotransfection of the DP-1 (1-205) mutant /which does not bind to E2F-1) with E2F-1 did not induce an increase in DNA-binding activity. Furthermore, E2F-1 (1-284), which binds DP-1, gave rise to an increase in DNA-binding activity when cotransfected with DP-1 (Fig. 5A). As shown in Figure 5B, the increased binding observed after cotransfection of E2F-1 and DP-1 was specific, because a wild-type but not a mutant E2F oligonucleotide competed for binding to the probe. The increased activity contained E2F-1 and DP-1, because a monoclonal antibody to E2F-1 (KH20) or the anti-HA tag antibody (12CA5, recognizing tagged DP-1) supershifted the complex. Two other monoclonal antibodies to either $\mathrm{pRB}$ or large $\mathrm{T}$ did not affect the increased activity, demonstrating the specificity of the supershifts seen with the $\mathrm{KH} 20$ and the 12CA5 antibodies. These results support the data obtained in vitro (Fig. 3) and show that E2F-1 and DP- 1 can bind DNA as a heterodimer.

Transfection of the C-33A cells with a pRB expression construct resulted in a faint band of supershifted E2F (Fig. 5A) and no increase in DNA-binding activity. Consistent with the above results, pRB, when transfected with either E2F-1 or DP-1 alone, did not lead to an increase in DNA-binding activity and did not change the pattern of bands seen when cells were only transfected with $\mathrm{pRB}$. However, when a triple transfection was performed, a slower migrating band containing E2F-1, DP-1, and $\mathrm{pRB}$ was seen (Fig. 5A,B). These data show that E2F- 

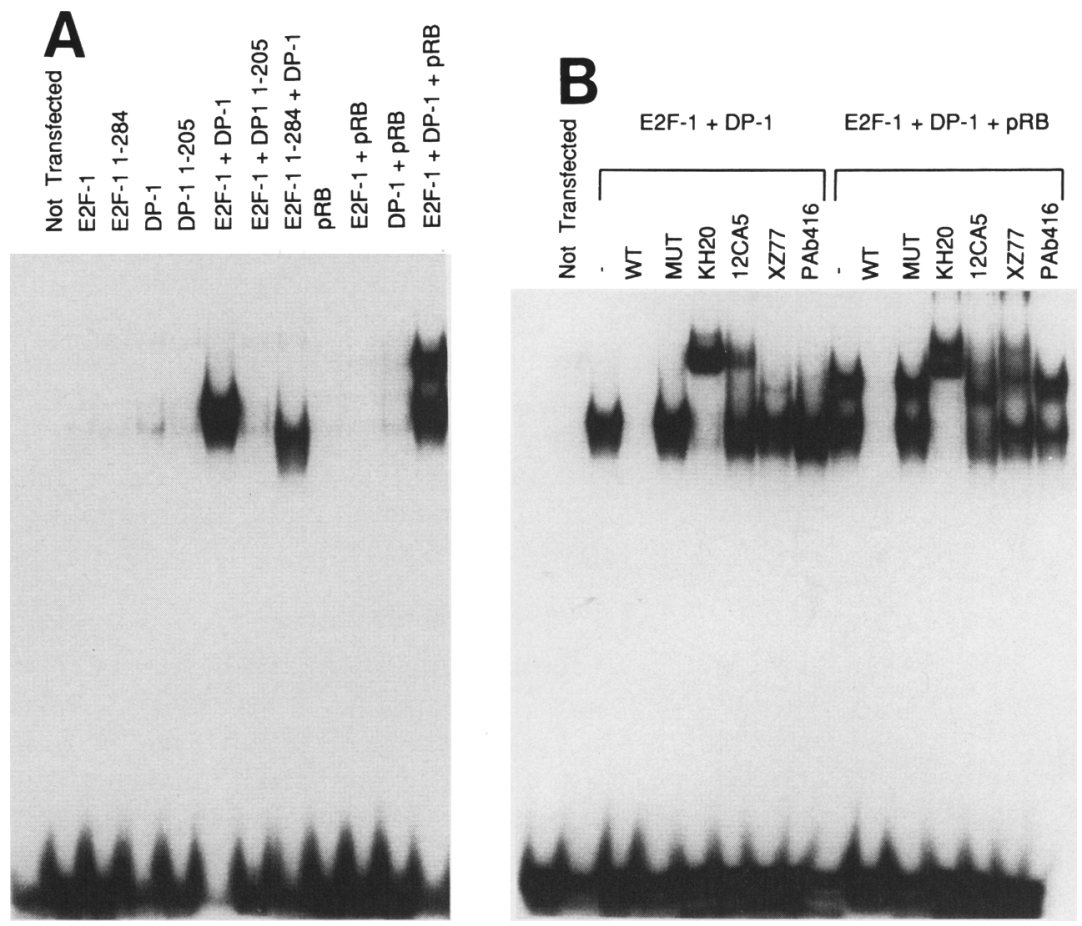

Figure 5. Coexpression of E2F-1 and DP-1 leads to increased DNA binding. $(A)$ C-33A cells were transfected with expression plasmids as indicated above each lane, and cell extracts were prepared as described in Materials and methods. Five micrograms of cell extract was tested for binding to a radiolabeled oligonucleotide containing the consensus E2F DNA-binding site. $(B)$ Cell extracts prepared from C-33A cells transfected with E2F-1 and DP-1 or E2F-1, DP-1, and pRB were tested for specific binding by cold oligonucleotides or antibodies. One hundred-fold excess of oligonucleotides containing wild-type (WT) or mutant (MUT) competitor oligonucleotides were added as indicated. The antibodies were as described in the legend to Fig. 4, and the PAb416 monoclonal antibody to SV40 large T served as a control.
1, DP-1, and pRB can form a trimolecular complex when bound to DNA, and they suggest that no additional protein is limiting for this interaction to take place.

\section{E2F-1 and DP-1 cooperate in trans-activation}

Several transcription factors have been shown to bind DNA as heterodimers (for review, see Jones 1990), and heterodimerization has been correlated with higher transcriptional activity (see Chiu et al. 1988; Sassone-Corsi et al. 1988; Amati et al. 1992; Kretzner et al. 1992). To examine the functional significance of E2F-1 and DP-1 heterodimerization, C-33A cells were transfected with increasing amounts of expression plasmids containing either E2F-1 (Fig. 6A) or DP-1 (Fig. 6B), along with a reporter plasmid containing four E2F-binding sites. When transfected alone, trans-activation by E2F-1 alone reached a maximum of 60 -fold above the endogenous activity (Fig. 6A). This activation was linear up to $20 \mathrm{ng}$ of input expression plasmid. In contrast, DP-1 led to a modest but significant trans-activation 10 -fold above the endogenous level of the reporter construct. Cotransfection of DP-1 and E2F-1 expression plasmids resulted in a significant increase of trans-activation as compared with either plasmid alone (Fig. 6). This increase in trans-activation was more than additive (160- to 180 -fold vs. 60 and 10-fold), suggesting that E2F-1 and DP-1 cooperate in trans-activation.

\section{Trans-activation by E2F-1 and DP-1 is repressed by $p R B$}

$\mathrm{pRB}$ has been shown previously to inhibit E2F-dependent (Hamel et al. 1992; Hiebert et al. 1992; Zamanian and La
Thangue 1992) and E2F-1-dependent (Helin et al. 1993) trans-activation. To determine whether trans-activation mediated by DP-1 and the E2F-1/DP-1 heterodimers was inhibited by pRB, C-33A cells were cotransfected with E2F-1, DP-1, and pRB (Fig. 7). E2F-1-mediated trans-activation of the reporter gene was inhibited by cotransfection of wild-type pRB but not by a naturally occurring mutant of pRB as described previously (Fig. 7; Helin et al. 1993). Similarly, DP-1-dependent trans-activation was inhibited by wild-type pRB, but not the mutated pRB, suggesting that the activation by DP- 1 is regulated by a similar mechanism as E2F-1-dependent trans-activation. As shown above (Fig. 6), cotransfection of E2F-1 and DP-1 led to a significant activation of transcription. This activation was inhibited by overexpression of $\mathrm{pRB}$ and not by the naturally occurring mutant of $\mathrm{pRB}$, demonstrating that E2F-1/DP-1-mediated trans-activation is behaving like endogenous "E2F" activity.

\section{Discussion}

In recent years a variety of transcription factors have been shown to bind DNA as heterodimers (Halazonetis et al. 1988; Kouzarides and Ziff 1988; Nakabeppu et al. 1988; Rauscher et al. 1988; Murre et al. 1989; Blackwood and Eisenman 1991). Heterodimerization appears necessary for high-affinity binding to DNA, and in the case of c-Fos/c-Jun (Chiu et al. 1988; Sassone-Corsi et al. 1988) and c-Myc/Max (Amati et al. 1992; Kretzner et al. 1992), dimerization has been correlated with higher transcriptional activity. Through analysis of the transcriptional activation mediated by E2F-1, we have now demonstrated that E2F-1 is able to dimerize with DP-1 in vivo 
A

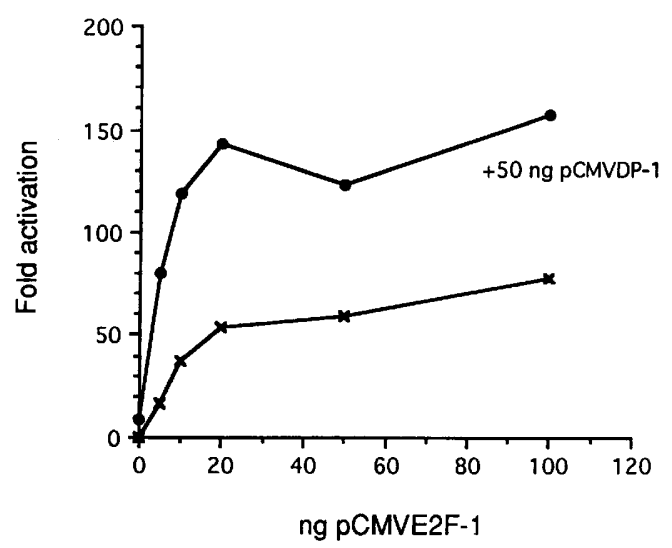

B

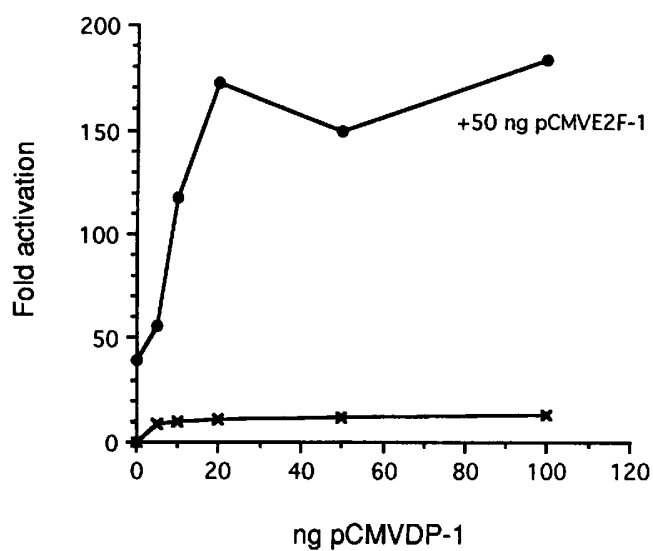

Figure 6. E2F-1 and DP-1 cooperate in trans-activation. $(A)$ $\mathrm{C}-33 \mathrm{~A}$ cells were transfected in duplicate with variable amounts of pCMVE2F-1 $(x)$ or variable amounts of pCMVE2F-1 in combination with $50 \mathrm{ng}$ of pCMVDP-1 (O), together with 2 $\mu \mathrm{g}$ of reporter construct containing four E2F DNA-binding sites in front of the cat gene $\left(\mathrm{E}_{2} \mathrm{~F}_{4} \mathrm{CAT}\right), 2 \mu \mathrm{g}$ of pRSVluciferase, and carrier DNA to a total of $22 \mu \mathrm{g} / 9-\mathrm{cm}$ dish. Fold activation refers to unit CAT activity normalized to the luciferase activity for

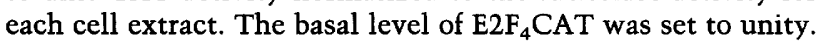
(B) C-33A cells were transfected as described in $A$, except pCMVDP-1 was transfected in variable amounts $(x)$. Data from the upper curve are from cells transfected with variable amounts of pCMVDP-1 and a fixed amount of pCMVE2F-1 (O). Fold activation was calculated as in $A$.

and in vitro. This dimerization leads to increased DNA binding and enhanced transcriptional activity. Furthermore, our results demonstrate that E2F-1 and DP-1 heterodimerization is required for efficient $\mathrm{pRB}$ binding. Finally, we have demonstrated that overexpression of wildtype but not mutant $\mathrm{pRB}$ inhibits trans-activation mediated by E2F-1, DP-1, and the E2F-1/DP-1 heterodimer.

Our in vivo and in vitro protein-protein interaction assays demonstrate that E2F-1 and DP-1 heterodimerize efficiently and that no other proteins are required for this interaction. Furthermore, we have mapped the regions in E2F-1 and DP-1 that are required for heterodimerization to amino acids 191-284 of E2F-1 and amino acids 205277 of DP-1 (Fig. 8A).
The data presented here are consistent with a recent observation that E2F binds to DNA as a heterodimer (Huber et al. 1993). Interestingly, Huber and colleagues identified five proteins in their final purification step from an E2F DNA-affinity column and showed by in vitro reconstitution experiments that the five proteins could be separated into two complementation groups. One group was shown to be immunologically related to E2F-1 (Huber et al. 1993; K. Helin, unpubl.), and the data presented here suggest that the second group of proteins is of the DP-1 family. When a purified fraction of E2F (kindly provided by $\mathrm{H}$. Huber) was probed with a polyclonal antibody to DP-1, two proteins from the second group were recognized by this antibody (K. Helin, unpubl.).

\section{Model for E2F-dependent trans-activation}

In Figure 8B we have outlined a model for how E2F-1and DP-1-dependent transcription is regulated. Several aspects of this model are still unclear; however, we now know that E2F-1 and DP-1 heterodimerize and that this heterodimerization can be correlated to an increase in

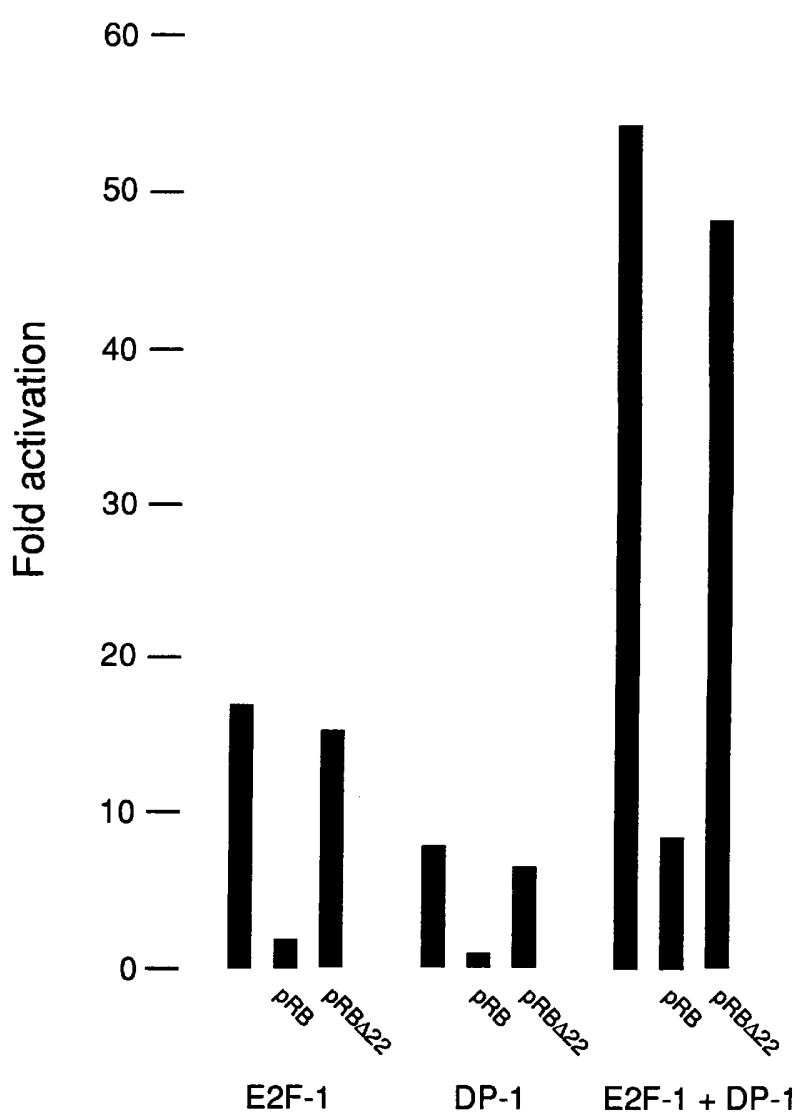

Figure 7. E2F-1/DP-1 trans-activation is inhibited by $\mathrm{pRB}$. C-33A cells were transfected with $10 \mathrm{ng}$ of pCMVE2F-1, $10 \mathrm{ng}$ of pCMVDP-1, or both. Together with the expression plasmids, the cells were transfected with $2 \mu \mathrm{g}$ of $\left(\mathrm{E}_{2} \mathrm{~F}_{4} \mathrm{CAT}\right), 2 \mu \mathrm{g}$ of pRSVluciferase, and carrier DNA as described in Fig. 6A. In addition, where indicated, $100 \mathrm{ng}$ of pCMVRB (pRB) or $100 \mathrm{ng}$ of pCMVRB 22 (pRB $\Delta 22$ ) was included in the transfection mixture. Fold activation was calculated as described in Fig. 6A. 


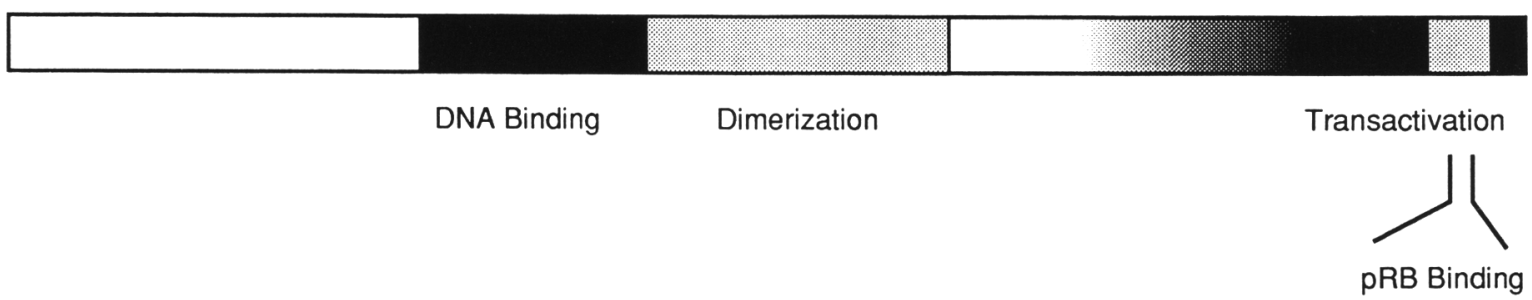

DP-1

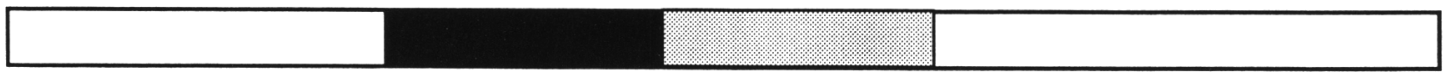

DNA Binding Dimerization
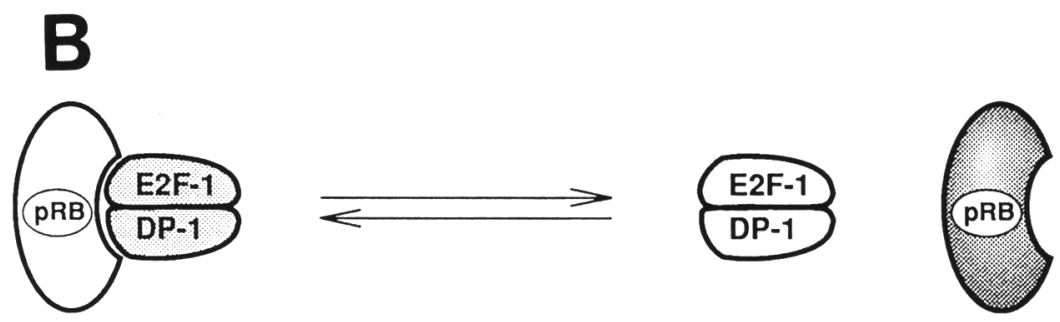

Figure 8. (A) Schematic structures of the human E2F-1 and DP-1 proteins. The human E2F-1 and human DP-1 proteins are of 437 or 410 amino acids, respectively. Functional domains have been mapped in these proteins: The DNA-binding domain (solid box) encompasses amino acids 120-191 in E2F-1 (Helin et al. 1992; K. Helin, unpubl.) and amino acids 84-204 in mouse DP-1 (Girling et al. 1993). The dimerization domain (shaded box) is contained within amino acids 191-284 in human E2F-1 and amino acids 205-277 in human DP-1 (this study). In addition, a carboxy-terminal trans-activation region has been mapped in human E2F-1 (Kaelin et al. 1992; Shan et al. 1992) and an 18-amino-acid pRB-binding domain (Helin et al. 1992). (B) Model for E2F-1/DP-1 trans-activation. The E2F-1/DP-1 heterodimer is inactive (shaded) when bound to $\mathrm{pRB}$ and active (open) when not complexed with $\mathrm{pRB}$. The interaction between the heterodimer and pRB is regulated presumably by phosphorylation of pRB, which is an active (open) inhibitor when bound to E2F-1/DP-1 and inactive (shaded) in its phosphorylated state. The direct contact between pRB and DP-1 presented in this model is as yet speculative.

transcription through E2F DNA-binding sites. Furthermore, it is clear from our studies that the heterodimer binds with much higher affinity to pRB than to E2F-1 alone. Finally, trans-activation mediated by the heterodimer can be regulated by $\mathrm{pRB}$, strongly suggesting that the trimolecular complex is transcriptionally inactive. Several factors are unknown in this model: Interaction of the human DP-1 with the cognate DNA-binding site is not detected easily, whereas the binding of GST-E2F-1 is readily observed (Helin et al. 1992; Kaelin et al. 1992; Shan et al. 1992). The binding of E2F-1 is, however, significantly reduced when the GST portion of the fusion protein is removed (Fig. 3). In a similar manner, we have found that histidine-tagged bacterial or baculovirus-expressed E2F-1 has very low affinity for the E2F DNAbinding site (K. Helin and B.D. Dynlacht, unpubl.). Taken together with the fact that overexpression of E2F-1 does not lead to any appreciable increase in DNAbinding activity (Fig. 5), it is unlikely that E2F-1 by itself binds DNA in the cell. In contrast, E2F-1 binds very efficiently to DNA when complexed to DP-1. It is not clear whether both proteins directly contact DNA; however, studies on the murine DP-1 have shown that it is capable of DNA binding (Girling et al. 1993), suggesting that both proteins can contact DNA. Future experiments will be necessary to determine whether the DNA-binding domains of both proteins are required for high-affinity DNA binding.

E2F-1/DP-1 heterodimerization is required for highaffinity pRB binding in vivo. This result was unexpected, because E2F-1 was cloned on the basis of its ability to directly bind pRB without any auxiliary proteins (Helin et al. 1992; Kaelin et al. 1992; Shan et al. 1992). The results presented here suggest that in the absence of DP1 , the interaction between E2F-1 and pRB is weak. The carboxy-terminal region of E2F-1 (encompassing the pRB-binding domain) is required for the trimolecular interaction, but future studies will be necessary to determine whether DP-1 contributes to $\mathrm{pRB}$ binding by directly contacting $\mathrm{pRB}$. Our studies suggest that no other proteins are necessary for the trimolecular complex to form. However, if additional factors are required for the formation of the pRB/E2F-1/DP-1 complex, they cannot be limiting, because even after overexpression of the 
three proteins, they still associate quantitatively (Figs. $4 \mathrm{C}$ and $5 \mathrm{~A})$.

How does DP-1 contribute to transcriptional activation? On the basis of our results, DP-1 is required for high-affinity DNA binding of E2F-1/DP-1 dimers; however, whether this protein contains a trans-activation domain like E2F-1 remains to be determined. It is possible that DP-1, like the Myc heterodimeric partner Max, does not contain a trans-activation domain (Kato et al. 1992) and that the trans-activation functions of "E2F" are mediated solely through the E2F-1 component.

Heterodimerization as a way to regulate transcriptional activity has been described for several other transcription factors (see above; Jones 1990). This mechanism is thought to add another level of regulation on transcriptional control and allows families of transcription factors (like E2F and DP) to form positively or negatively acting complexes in expanded combinations. The various components participating in the heterodimeric complexes would determine whether an active "transcription factor" can form. It is therefore important to investigate the transcriptional regulation of the genes encoding such components and determine the expression patterns of the proteins. In this regard, it is interesting to note that E2F-1 mRNA is synthesized in a cell cycle-dependent manner (Kaelin et al. 1992; Shan et al. 1992). Furthermore, several cellular genes that contain E2F sites within their promoters appear to be synthesized at different stages of the cell cycle (Nevins 1992; Helin and Harlow 1993). The c-myc gene, for example, is known as an immediate-early gene and DHFR transcription is turned on at the $G_{1} / S$ boundary of the cell cycle. These observations indicate that different "E2Fs" may regulate the transcription of the E2F-responsive genes and that the formation of the active "E2F" is governing whether their transcription occurs. Complementary to this model, we have recently cloned cDNAs for human proteins related to E2F-1 (J.A. Lees, M. Saito, M. Vidal, M. Valentine, T. Look, E. Harlow, N. Dyson, and K. Helin, in prep.) and DP-1 (C.-L. Wu and E. Harlow, unpubl.). These newly cloned cDNAs may account for the total "E2F" activity present in the cell; and on the basis of our results, we propose that "E2F" is the activity generated when an E2F protein and a DP protein dimerize. The cloning of the members of the E2F and DP families, and the observation that E2F/DP associate to form an "E2F" transcription factor will promote the further investigation of when and how E2F-dependent transcription can occur.

\section{Materials and methods}

\section{Cloning of human DP-1}

First-strand cDNA was made from poly $(\mathrm{A})^{+}$RNA, prepared from mouse proB NFS-70 cells (a kind gift of S. Pillai, MGH Cancer Center), by using random hexanucleotides (Pharmacia), and Moloney murine reverse transcriptase (BRL) using standard techniques (Sambrook et al. 1989). A probe for cloning human $D P-1$ was then generated by the polymerase chain reaction (PCR) method, using primers whose sequence was derived from the published $D P-1$ nucleotide sequence (Girling et al. 1993). The PCR product was cloned into pBluescript SK + (Stratagene), and by DNA sequencing it was confirmed that the generated product was genuine mouse $D P-1$. The PCR product was radiolabeled and used to screen a cDNA library prepared from a human pre-B-cell line, Nalm 6 (kindly provided by A. Bernards, MGH Cancer Center). Three independent human DP-1 clones were isolated. The clone with the largest insert $(2.1 \mathrm{~kb})$ was then sequenced. Double-stranded DNA sequencing was performed using Sequenase 2.0 (U.S. Biochemical) according to the manufacturer's procedure. Mouse DP-1 cDNA la kind gift of $\mathbf{R}$. Girling/ was partly sequenced using specific primers for the carboxyl terminus of the DP-1 open reading frame.

\section{Construction of plasmids}

pGST-DP-1 (1-410), pGST-DP-1 (1-277), and pGST-DP-1 (1205) were all constructed by cloning PCR-amplified DP-1 sequences into the BamHI site of pGST2TK (Kaelin et al. 1992). pGST-E2F-1 (89-437), pGST-E2F-1 (223-437), pGST-E2F-1 (386-437), pGST-E2F-1 (89-238), and pGST-E2F-1 (89-191) have been described before (Helin et al. 1992). pGST-E2F-1 (1437) was constructed by isolating a BamHI fragment containing the full-length E2F-1 cDNA from pCMVE2F-1 (Helin et al. 1993), which was cloned into pGST20T. pGST (1-284) was generated by cloning a BamHI-BglII fragment of the E2F-1 cDNA into the BamHI site of pGST2TK. pGSTE2F-1 (1-191) was generated by excising a BamHI fragment containing the E2F-1 DNA sequences coding for amino acids 1-191 and an in-frame stop codon from pCMVE2F-1 (1-191; K. Helin, unpubl.) into the BamHI site of pGST2TK. pGSTE2F-1 (284-437) was constructed by subcloning a $B g$ II-BamHI fragment from pBSKHAE2F-1 (K. Helin, unpubl.) into pGEX30X. The plasmid used for in vitro transcription of E2F-1 (pBSKE2F-1 $\beta$-globin) has been described (Fattaey et al. 1993).

For expression studies the following plasmids were used: pCMVE2F-1 has been described (Helin et al. 1993); pCMVE2F-1 (1-284), pCMVDP-1, pCMVHADP-1, and pCMVHADP-1 (1-205) were all generated by blunt-end cloning the cDNAs encoding for the desired proteins into blunt-ended pCMVneoBam (Baker et al. 1990). The insert for pCMVE2F-1 (1-284) was isolated from pGSTE2F-1 (1-284), and the insert for PCMVDP-1 was isolated from the original $D P-1$ clone. To generate the HAtagged versions of DP-1, pBSKHA tag was first generated by synthesizing complementary oligonucleotides containing the open reading frame for the HA tag (Field et al. 1988) and cloning the annealed oligonucleotides into pBSK + (Stratagene). The expression plasmids for the HA-DP-1s were then generated by inserting the corresponding cDNAs into pBSKHA tag, resulting in pBSKHADP-1 (amino acids 1-205) and pBSKHADP-1. From these plasmids, inserts were isolated and cloned into pCMVneoBam. pCMVRB and PCMVRB $\triangle 22$ have been described previously (Qin et al. 1992).

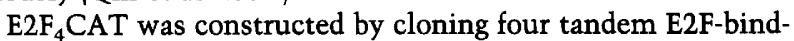
ing sites from the E2A promoter $(-71$ to -54 ; Loeken and Brady 1989) into a blunt-ended Sall site of ElbCAT (Lillie and Green 1989). The sequence and the orientation of the binding sites were confirmed by DNA sequencing. In all cases where inserts were generated by PCR, the nucleotide sequence in the resulting plasmid inserts were confirmed by DNA sequencing.

\section{Expression and purification of GST fusion proteins}

Proteins were expressed and purified from Escherichia coli as described by Smith and Johnson (1988). After binding to glutathione-agarose, the proteins were washed and eluted with re- 
duced glutathione (Sigma) and the concentration determined by the method of Bradford (Bio-Rad). The purity and size of the eluted proteins were then evaluated by Coomassie staining of SDS-polyacrylamide gels (Laemmli and Favre 1973; Harlow and Lane 1988).

To cleave GST-E2F-1 (1-284) with thrombin, the GST fusion protein immobilized on agarose beads was washed twice with cleavage buffer ( $50 \mathrm{~mm}$ HEPES ( $\mathrm{pH} 7.0), 100 \mathrm{~mm} \mathrm{NaCl}, 5 \mathrm{~mm}$ $\mathrm{CaCl}_{2}$ ). The washed beads were resuspended in cleavage buffer containing 0.05 units of human thrombin (Sigma) per microgram of GST fusion protein and rocked for $1 \mathrm{hr}$ at room temperature. The reaction was terminated by addition of EDTA to a final concentration of $5 \mathrm{~mm}$. The protein solution was then concentrated using a Centricon 30 concentrator (Amicon), and the size and purity of the protein was determined by SDS-PAGE followed by Coomassie blue staining.

\section{In vitro-binding experiments}

cRNA was synthesized by in vitro transcription using T7 RNA polymerase (Promega). The resulting cRNA was translated in rabbit reticulocyte lysate (Promega) in the presence of $\left[{ }^{35} \mathrm{~S}\right] \mathrm{me}$ thionine (New England Nuclear). The synthesized polypeptides (5 or $10 \mu \mathrm{l}$ ) were mixed with GST fusion proteins $(5 \mu \mathrm{g})$ in $0.1 \mathrm{M}$ HEMG (25 mM HEPES at pH 7.6, 0.1 mM EDTA, $10 \mathrm{~mm} \mathrm{MgCl}_{2}$, $10 \%$ glycerol, $0.1 \% \mathrm{NP}-40,0.1 \mathrm{M} \mathrm{KCl}$, and $1 \mathrm{mM}$ DTT). The GST fusion protein and any associated proteins were then recovered using glutathione-agarose (Sigma), washed three times with E1A lysis buffer (50 mM HEPES at pH 7.0, $250 \mathrm{~mm} \mathrm{NaCl}$, and $0.1 \%$ NP- 40 ), resolved on $8 \%$ SDS-polyacrylamide gels, and detected by fluorography (Harlow and Lane 1988).

\section{Immunological reagents}

Antibodies to human RB (XZ77), SV40 T (Pab416), and HA tag have been described previously (Harlow et al. 1981; Field et al. 1988; Hu et al. 1991). To prepare monoclonal antibodies to E2F1 , a bacterial expression plasmid containing histidine-tagged E2F-1 (1-437) was constructed by cloning the full-length open reading frame of E2F-1 into PQE9 (Qiagen). Protein was made and purified according to a manual supplied by Qiagen, and it was used to immunize mice as described by Harlow and Lane (1988). Monoclonal antibodies were prepared by fusing splenocytes to NS-1 myeloma cells 3 days after the final boost. Positive tissue culture supernatants were identified by immunoprecipitation of $\left[{ }^{35} \mathrm{~S}\right]$ methionine-labeled E2F-1 protein synthesized in vitro. Twenty-nine different cell lines producing monoclonal antibodies to E2F-1 were generated by single-cell cloning. For the experiments described in this paper, we used the $\mathrm{KH} 11$, $\mathrm{KH} 20, \mathrm{KH} 67$, and KH95 monoclonal antibodies to E2F-1. KH11 and $\mathrm{KH} 67$ are of the IgG2b subclass and recognize epitopes in E2F-1 between amino acids 223 and 238 (KH1 1) and amino acids 89 and 191 (KH67). KH20 is an IgG2a that recognizes an aminoterminal epitope in E2F-1 (amino acids 1-89). KH95 is an IgG2a recognizing an epitope between amino acids 342 and 386 in E2F-1. The polyclonal antibody to GST-DP-1 was generated by immunizing mice with GST-DP-1 (1-205).

\section{Gel-retardation assays}

Gel-retardation assays were performed as described previously (Helin et al. 1992). Five micrograms of cell extract was used directly in a binding buffer containing $20 \mathrm{~mm}$ HEPES ( $\mathrm{pH} 7.6)$, $40 \mathrm{mM} \mathrm{KCl}, 1 \mathrm{~mm} \mathrm{MgCl} 2,0.1 \mathrm{~mm}$ EDTA, and $0.1 \% \mathrm{NP}-40$ to which $0.1-0.5 \mathrm{ng}$ of ${ }^{32} \mathrm{P}$-labeled probe and $2 \mu \mathrm{g}$ sonicated salmon sperm DNA was added. Gel-retardation assays with GST fusion proteins or purified E2F-1 (1-284) were performed using 20-100 $\mathrm{ng}$ of the protein in binding buffer. To test for the presence of specific proteins, $1 \mu \mathrm{l}$ of tissue culture supernatant or polyclonal mouse antibody was included in the binding reaction. To test for specificity of binding, a 100-fold excess of wild-type or mutant oligonucleotide was added in the binding reaction. The reaction products were separated on a $4 \%$ polyacrylamide gel in $0.25 \times \mathrm{TBE}$ at $4^{\circ} \mathrm{C}$ at $180 \mathrm{~V}$. The gel was then dried and exposed to film. E2F oligonucleotides for gel-retardation assays were as described by Helin et al. (1992)

\section{Tissue culture and labeling}

The human cervical carcinoma cell line C-33A (ATCC No. HTB31) was grown in Dulbecco's modified Eagle medium (DMEM) supplemented with $10 \%$ fetal bovine serum. For labeling with $\left[{ }^{35} \mathrm{~S}\right]$ methionine, cells were incubated for $3 \mathrm{hr}$ at $37^{\circ} \mathrm{C}$ in $4 \mathrm{ml}$ of methione-free labeling media containing $0.5 \mathrm{mCi}$ of Trans ${ }^{35} \mathrm{~S}$-label (New England Nuclear) per 9-cm plate.

\section{Immunoprecipitation}

Cells were lysed in ElA lysis buffer containing 5 mM EDTA, 1 $\mathrm{mM} \mathrm{DTT}, 50 \mu \mathrm{g} / \mathrm{ml}$ of PMSF, $1 \mu \mathrm{g} / \mathrm{ml}$ of leupeptin, and $1 \mu \mathrm{g} / \mathrm{ml}$ of aprotinin and immunoprecipitated as described previously (Harlow et al. 1985). The precipitated proteins were then separated by SDS-PAGE and visualized by fluorography.

\section{Transient transfections}

C-33A cells were transfected essentially as described by Graham and van der Eb (1973). For labeling and preparation of cell extracts, cells were transfected with $8 \mu \mathrm{g}$ of expression plasmid, and carrier (pBSK + ) was added to a total of $24 \mu \mathrm{g}$. For chloramphenicol acetyltransferase (CAT) assays, cells were transfected with the expression vector as indicated throughout the text together with $2 \mu \mathrm{g}$ of $\mathrm{E}_{2} \mathrm{~F}_{4} \mathrm{CAT}, 2 \mu \mathrm{g}$ of pRSVluciferase, and $\mathrm{pBSK}+$ to a total of $22 \mu \mathrm{g} / 9-\mathrm{cm}$ plate. Cells were harvested or labeled $36 \mathrm{hr}$ after transfection.

\section{Preparation of whole-cell extracts}

Whole-cell extracts were prepared from transfected cells by adding two packed cell volume of buffer $\mathrm{C}(20 \mathrm{mM}$ HEPES at $\mathrm{pH} 7.6$, $0.42 \mathrm{M} \mathrm{NaCl}, 1.5 \mathrm{~mm} \mathrm{MgCl} 2,0.2 \mathrm{~mm}$ EDTA, $0.5 \mathrm{~mm}$ PMSF, 0.5 mM DTT, $25 \%$ glycerol). The resuspended cells were then transferred to Beckman TLA 100 centrifuge tubes (Beckman), and the concentration of $\mathrm{NaCl}$ was adjusted to $0.42 \mathrm{M}$ (final concentration) by addition of $5 \mathrm{M} \mathrm{NaCl}$. The cells were freezed/thawed once and left on ice for $20 \mathrm{~min}$. Extracts were centrifuged at $100,000 \mathrm{~g}$ for $20 \mathrm{~min}$, and the supernatants were used for gelretardation assays.

\section{CAT and luciferase assays}

Thirty-six hours after transfection, the transfected cells were resuspended in $0.025 \mathrm{M}$ Tris- $\mathrm{HCl}(\mathrm{pH} 8.0)$. The cells were freezed/thawed three times and centrifuged at $15,000 \mathrm{~g}$ for 10 min. Supernatants were assayed for CAT and luciferase activities according to Sleigh (1986) and De Wet et al. (1987).

\section{Acknowledgments}

We thank S. Pillai, A. Bernards, R. Girling, and H. Huber for reagents and S. J. L. van den Heuvel for careful reading of the manuscript. K.H., C.-L.W., A.R.F., J.A.L., and B.D.D. are sup- 
ported by fellowships from the Danish Medical Research Council, the National Institutes of Health, the National Institutes of Health, the American Leukemia Society, and the Damon Runyon Foundation, respectively. E.H. is an American Cancer Society Research Professor. This work was supported by grants from the National Institutes of Health and Massachusetts General Hospital to E.H.

The publication costs of this article were defrayed in part by payment of page charges. This article must therefore be hereby marked "advertisement" in accordance with 18 USC section 1734 solely to indicate this fact.

\section{References}

Amati, B., S. Dalton, M.W. Brooks, T.D. Littlewood, G.I. Evan, and $H$. Land. 1992. Transcriptional activation by the human c-Myc oncoprotein in yeast requires interaction with Max. Nature 359: 423-426.

Bagchi, S., P. Raychaudhuri, and J. Nevins. 1990. Adenovirus E1A proteins can dissociate heteromeric complexes involving the E2F transcription factor: A novel mechanism for E1A trans-activation. Cell 62: 659-669.

Bagchi, S., R. Weinmann, and P. Raychaudhuri. 1991. The retinoblastoma protein copurifies with E2F-I, an E1A-regulated inhibitor of the transcription factor E2F. Cell 65: 1063-1072.

Baker, S.J., S. Markowitz, E.R. Fearon, J.K.V. Willson, and B. Vogelstein. 1990. Suppression of human colorectal carcinoma cell growth by wild-type p53. Science 249: 912-915.

Bandara, L.R. and N.B. La Thangue. 1991. Adenovirus Ela prevents the retinoblastoma gene product from complexing with a cellular transcription factor. Nature 351: 494-497.

Bandara, L.R., J.P. Adamczewski, T. Hunt, and N. La Thangue. 1991. Cyclin A and the retinoblastoma gene product complex with a common transcription factor. Nature 352: 249251.

Blackwood, E.M. and R.N. Eisenman. 1991. Max: A helix-loophelix zipper protein that forms a sequence-specific DNAbinding complex with Myc. Science 251: 1211-1217.

Blake, M.C. and J.C. Azizkhan. 1989. Transcription factor E2F is required for efficient expression of the hamster dihydrofolate reductase gene in vitro and in vivo. Mol. Cell. Biol. 9: 4994 5002 .

Cao, L., B. Faha, M. Dembski, L.-H. Tsai, E. Harlow, and N. Dyson. 1992. Independent binding of the retinoblastoma protein and p107 to the transcription factor E2F. Nature 355: 176-179.

Chellappan, S., S. Hiebert, M. Mudryj, J. Horowitz, and J. Nevins. 1991. The E2F transcription factor is a cellular target for the RB protein. Cell 65: 1053-1061.

Chittenden, T., D. Livingston, and W. Kaelin. 1991. The T/ElAbinding domain of the retinoblastoma product can interact selectively with a sequence-specific DNA-binding protein. Cell 65: 1073-1082.

Chiu, R., W.J. Boyle, J. Meek, T. Smeal, T. Hunter, and M. Karin. 1988. The c-Fos protein interacts with c-Jun/AP-1 to stimulate transcription of AP-1 responsive genes. Cell 54: 541552.

Dalton, S. 1992. Cell cycle regulation of the human cdc2 gene. EMBO I. 11: 1797-1804.

Devoto, S.H., M. Mudryj, J. Pines, T. Hunter, and J.R. Nevins. 1992. A cyclin A- specific protein kinase complex possesses sequence-specific DNA binding activity: p33cdk2 is a component of the E2F-cyclin A complex. Cell 68: 167-176.

De Wet, J.R., K.V. Wood, M. DeLuca, D.R. Helinski, and S. Subramani. 1987. Firefly luciferase gene: Structure and expression in mammalian cells. Mol. Cell. Biol. 7: 725-737.
Fattaey, A.R., E. Harlow, and K. Helin. 1993. Independent regions of adenovirus ElA are required for binding to and dissociation of E2F-protein complexes. Mol. Cell. Biol. (in press).

Field, J., J.-I. Nikawa, D. Broek, B. MacDonald, L. Rodgers, I.A. Wilson, R.A. Lerner, and M. Wigler. 1988. Purification of a RAS-responsive adenylyl cyclase complex from Saccharomyces cerevisiae by use of an epitope addition method. Mol. Cell. Biol. 8: 2129-2165.

Girling, R., J.F. Partridge, L.R. Bandara, N. Burden, N.F. Totty, J.J. Hsuan, and N.B. La Thangue. 1993. A new component of the transcription factor DRTF1/E2F. Nature 362: 83-87.

Goodrich, D.W., N.P. Wang, Y.-W. Qian, E.Y.-H. P. Lee, and W.-H. Lee. 1991. The retinoblastoma gene product regulates progression through the G1 phase of the cell cycle. Cell 67: 293-302.

Graham F.L. and A.J. van der Eb. 1973. A new technique for the assay of infectivity of human adenvirus. Virology 52: 456467.

Halazonetis, T.D., K. Georgopoulos, M.E. Greenberg, and P. Leder. 1988. c-Jun dimerizes with itself and with c-Fos, forming complexes of different DNA binding affinities. Cell 55: $917-$ 924.

Hamel, P.A., R.M. Gill, R.A. Phillips, and B.L. Gallie. 1992. Transcriptional repression of the E2-containing promoters EIIaE, c-myc, and RB1 by the product of the RB1 gene. Mol. Cell. Biol. 12: 3431-3438.

Harlow, E. and D. Lane. 1988. Antibodies: A laboratory manual. Cold Spring Harbor Laboratory, Cold Spring Harbor, New York.

Harlow, E., L.V. Crawford, D.C. Pim, and N.M. Williamson. 1981. Monoclonal antibodies specific for simian virus 40 tumor antigens. I. Virol. 39: 861-869.

Harlow, E., B.R. Franza, and C. Schley. 1985. Monoclonal antibodies specific for adenovirus early region E1A proteins: Extensive heterogeneity in early region 1A products. J. Virol. 55: 533-546.

Harlow, E., P. Whyte, B.R. Franza, and C. Schley. 1986. Association of adenovirus early-region 1A proteins with cellular polypeptides. Mol. Cell. Biol. 6: 1579-1589.

Helin, K. and E. Harlow. 1993. The retinoblastoma protein as a transcriptional repressor. Trends Cell Biol. 3: 43-46.

Helin, K., E. Harlow, and A.R. Fattaey. 1993. Inhibition of E2F-1 transactivation by direct binding of the retinoblastoma protein. Mol. Cell. Biol. (in press).

Helin, K., J.A. Lees, M. Vidal, N. Dyson, E. Harlow, and A. Fattaey. 1992. A cDNA encoding a pRB-binding protein with properties of the transcription factor E2F. Cell 70: 337-350.

Hiebert, S.W., S.P. Chellappan, J.M. Horowitz, and J.R. Nevins. 1992. The interaction of $\mathrm{pRb}$ with E2F inhibits the transcriptional activity of E2F. Genes \& Dev. 6: 177-185.

Hiebert, S.W., M.Lipp, and J.R. Nevins. 1989. ElA-dependent trans-activation of the human MYC promoter is mediated by the E2F factor. Proc. Natl. Acad. Sci. 86: 3594-3598.

Hinds, P.W., S. Mittnacht, V. Dulic, A. Arnold, S.I. Reed, and R.A. Weinberg. 1992. Regulation of retinoblastoma protein functions by ectopic expression of human cyclins. Cell 70: 993-1006.

Hu, Q., C. Bautista, G. Edwards, D. Defeo-Jones, R. Jones, and E. Harlow. 1991. Antibodies specific for the human retinoblastoma protein identify a family of related polypeptides. Mol. Cell. Biol. 11: 5792-5799.

Huber, H.E., G. Edwards, P.J. Goodhart, D.R. Patrick, P.S. Huang, M. Ivey-Hoyle, S.F. Barnett, A. Oliff, and D.C. Heimbrook. 1993. Transcription factor E2F binds DNA as a heterodimer. Proc. Natl. Acad. Sci. 90: 3525-3529. 
Jones, N. 1990. Transcriptional regulation by dimerization: Two sides to an incestuous relationship. Cell 61: 9-11.

Kaelin, W.G., W. Krek, W.R. Sellers, J.A. DeCaprio, F. Ajchanbaum, C.S. Fuchs, T. Chittenden, Y. Li, P.J. Farnham, M.A. Blanar, D.M. Livingston, and E.K. Flemington. 1992. Expression cloning of a cDNA encoding a retinoblastoma-binding protein with E2F-like properties. Cell 70: 351-364.

Kato, G.J., W.M.F. Lee, L. Chen, and C.V. Dang. 1992. Max: functional domains and interaction with c-Myc. Genes \& Dev. 6: 81-92.

Kouzarides, T. and E. Ziff. 1988. The role of the leucine zipper in the Fos-Jun interaction. Nature 336: 646-651.

Kovesdi, I., R. Reichel, and J.R. Nevins. 1986. Identification of a cellular transcription factor involved in E1A trans-activation. Cell 45: 219-228.

Kretzner, L., E.M. Blackwood, and R.N. Eisenman. 1992. Myc and Max proteins possess distinct transcriptional activities. Nature 359: 426-429.

Laemmli, U.K. and M. Favre. 1973. Maturation of the head of bacteriophage T4. I. DNA packing events. J. Mol. Biol. 80: $575-599$.

Lees, E., B. Faha, V. Dulic, S.I. Reed, and E. Harlow. 1992. Cyclin $\mathrm{E} / \mathrm{cdk} 2$ and cyclin A/cdk2 kinases associate with p107 and E2F in a temporally distinct manner. Genes \& Dev. 6: 1874 1885.

Lillie, J.W. and M.R. Green. 1989. Transcription activation by the adenovirus E1A protein. Nature 338: 39-44.

Loeken, M.R. and J. Brady. 1989. The Adenovirus EIIA enhancer. Analysis of regulatory sequences and changes in binding activity of ATF and EIIF following adenovirus infection. J. Biol. Chem. 264: 6572-6579.

Means, A.L., J.E. Slansky, S.L. McMahon, M.W. Knuth, and P.J. Farnham. 1992. The HIP binding site is required for growth regulation of the dihydrofolate reductase promoter. Mol. Cell. Biol. 12: 1054-1063.

Murre, C., P.S. McCaw, H. Vaessin, M. Caudy, L.Y. Jan., Y.N. Jan, C.V. Cabrera, J.N. Buskin, S.D. Hauschka, A.B. Lassar, H. Weintraub, and D. Baltimore. 1989. Interactions between heterologous helix-loop-helix proteins generate complexes that bind specifically to a common DNA sequence. Cell 58: $537-544$.

Nakabeppu, Y., K. Ryder, and D. Nathans. 1988. DNA binding activities of three murine Jun proteins: Stimulation by Fos. Cell 55: 907-915.

Nevins, J.R. 1992. E2F: A link betwen the Rb Tumor suppressor protein and viral oncoproteins. Science 258: 424-429.

Pearson, B.E., H.P. Nasheuer, and T.S. Wang. 1991. Human DNA polymerase alpha gene: Sequences controlling expression in cycling and serum-stimulated cells. Mol. Cell. Biol. 11: 2081-2095.

Qin, X.-Q., T. Chittenden, D. Livingston, and W.G. Kaelin. 1992. Identification of a growth suppression domain within the retinoblastoma gene product. Genes \& Dev. 6: 953-964.

Rauscher, F.J. I., R.R. Cohen, T. Curran, T.J. Bos, P.K. Vogt, D. Bohman, R. Tjian, and B.R. Franza. 1988. Fos-associated protein $\mathrm{p} 39$ is the product of the jun proto-oncogene. Science 240: $1010-1016$.

Sambrook, J., E.F. Fritsch, and T. Maniatis. 1989. Molecular cloning: A laboratory manual. Cold Spring Harbor Laboratory Press, Cold Spring Harbor, New York.

Sassone-Corsi, P., W.W. Lamph, M. Kamps, and I.M. Verma. 1988. fos-Associated cellular p39 is related to nuclear transcription factor AP-1. Cell 54: 553-560.

Scheffner, M., K. Münger, J.C. Byrne, and P.M. Howley. 1991. The state of the p53 and retinoblastoma genes in human cervical carcinoma cell lines. Proc. Natl. Acad. Sci. 88: 5523-5527.
Schwarz, J.K., S.H. Devoto, E.J. Smith, S.P. Chellappan, L. Jakoi, and J.R. Nevins. 1993. Interactions of the p107 and Rb proteins with $\mathrm{E} 2 \mathrm{~F}$ during the cell proliferation response. $E M B O$ J. 12: 1013-1020.

Shan, B., X. Zhu, P.-L. Chen, T. Durfee, Y. Yang, D. Sharp, and W.-H. Lee. 1992. Molecular cloning of cellular genes encoding retinoblastoma-associated proteins: Identification of a gene with properties of the transcription factor E2F. Mol. Cell. Biol. 12: 5620-5631.

Shirodkar, S., M. Ewen, J.A. DeCaprio, D. Morgan, D. Livingston, and T. Chittenden. 1992. The transcription factor E2F interacts with the retinoblastoma product and a p107-cyclin A complex in a cell cycle-regulated manner. Cell 68: 157166.

Slansky, J., Y. Li, W.G. Kaelin, and P.J. Farnham. 1993. A protein synthesis-dependent increase in E2F1 mRNA correlates with growth regulation of the dihydrofolate reductase promoter. Mol. Cell. Biol. 13: 1610-1618.

Sleigh, M.J. 1986. A nonchromatographic assay for expression of the chloramphenicol acetyltransferase gene in eukaryotic cells. Anal. Biochem. 156: 251-256.

Smith, D.B. and K.S. Johnson. 1988. Single-step purification of polypeptides expressed in Escherichia coli as fusions with glutathione S-transferase. Gene 67: 31-40.

Thalmeier, K., H. Synovzik, R. Mertz, E.-L.Winnacker, and M. Lipp. 1989. Nuclear factor E2F mediates basic transcription and trans-activation by Ela of the human MYC promoter. Genes \& Dev. 3: 527-536.

Yee, A.S., P. Raychaudhuri, L. Jakoi, and J.R. Nevins. 1989. The adenovirus-inducible factor E2F stimulates transcription after specific DNA binding. Mol. Cell. Biol. 9: 578-585.

Yee, S.P. and P.E. Branton. 1985. Detection of cellular proteins associated with human adenovirus type 5 early region $1 \mathrm{~A}$ polypeptides. Virology 147: 142-153.

Zamanian, M. and N.B. La Thangue. 1992. Adenovirus ElA prevents the retinoblastoma gene product from repressing the activity of a cellular transcription factor. $E M B O J$. 11: 26032610.

- 1993. Transcriptional repression by the Rb-related protein p107. Mol. Biol. Cell 4: 389-396.

Zhu, L., S. van den Heuvel, K. Helin, A. Fattaey, M. Ewen, D. Livingston, N. Dyson, and E. Harlow. 1993. Inhibition of cell proliferation by 107 , a relative of the retinoblastoma protein. Genes \& Dev. 7: 1111-1125. 


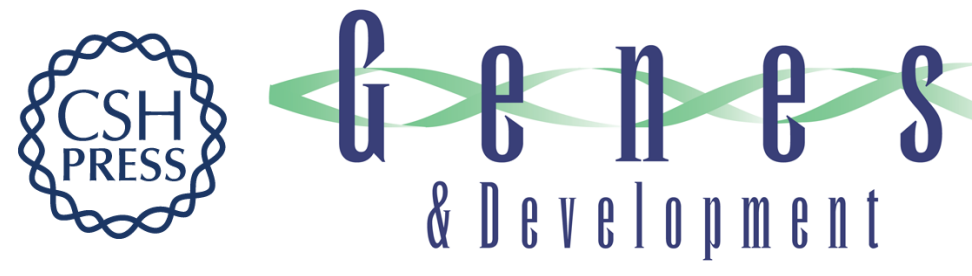

\section{Heterodimerization of the transcription factors E2F-1 and DP-1 leads to cooperative trans-activation.}

K Helin, C L Wu, A R Fattaey, et al.

Genes Dev. 1993, 7:

Access the most recent version at doi:10.1101/gad.7.10.1850

References This article cites 62 articles, 27 of which can be accessed free at:

http://genesdev.cshlp.org/content/7/10/1850.full.html\#ref-list-1

License

Email Alerting

Service

Receive free email alerts when new articles cite this article - sign up in the box at the top right corner of the article or click here.

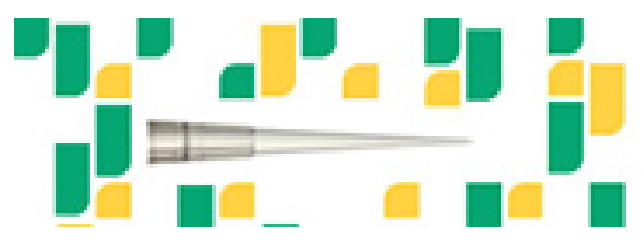

Focused on your science. 